\title{
Polyp Bail-Out: An Escape Response to Environmental Stress and a New Means of Reproduction in Corals
}

\author{
Paul W. Sammarco \\ Australian Institute of Marine Science, P.M.B. No. 3, Townsville M.S.O., Queensland 4810, Australia
}

\begin{abstract}
During a study of planulation in the central region of the Great Barrier Reef, it was determined that the coral Seriatopora hystrix Dana exhibits an escape response to environmental stress. This response, which occurs relatively rapidly, has been termed 'polyp bail-out'. It proceeded in 3 steps: (1) Isolation of individual polyps via the polyp-ward movement of coenosarc; (2) emergence of polyps and detachment from the skeleton; (3) dispersal, re-attachment to the bottom, and secretion of a new skeleton. Of the 250 polyps observed $\leqslant 5 \%$ successfully settled and secreted skeletons within 7 to 9 d under laboratory conditions. Polyps retained zooxanthellae during the process and usually possessed 2 slightly adhesive filaments which may have assisted in re-attachment. Bail-out may be induced at any time in the laboratory and has been observed to occur naturally in the field on several occasions. The peak period of planulation for $S$. hystrix was determined to be November (early summer, southern hemisphere). During the normal spawning period, some polyps were observed to detach themselves while carrying active planulae. These polyps later disintegrated, releasing the larvae which settled normally. It is suggested that 'bail-out' may be one factor contributing to dominance of this species within certain reef habitats. It would also appear that this process of isolation and detachment of individuals from a coral followed by dispersal, re-settlement, and re-initiation of skeletenogenesis, represents a previously unknown mode of asexual reproduction in the Scleractinia.
\end{abstract}

\section{INTRODUCTION}

Reproduction in scleractinian corals has been a largely ignored area of scientific enquiry for many years. Only recently has a substantial amount of information been added to our knowledge of this basic biological process within this group of invertebrates.

It has long been known that corals utilize both sexual and asexual means of reproduction. Sexual reproduction may involve internal fertilization and the brooding of planulae within the gastrovascular cavity. This has been well documented in numerous species throughout the world (Marshall and Stephenson, 1933; Hyman, 1940; Atoda, 1947a, b, 1951; Harrigan, 1972; Connell, 1974; Stimson, 1976, 1978; Rinkevich and Loya, $1979 a$, b). Sexual reproduction may also involve the spawning of sperm and eggs with external fertilization and subsequent planktonic development of larvae (Gardiner, 1902; Marshall and Stephenson, 1933; Kojis and Quinn, 1981, in press).

Asexual reproduction, considered here to be the pro- cess by which an increase in colony numbers is achieved without the aid of genetic recombination (sensu Giese and Pearse, 1974; Harper, 1977), is presently known to be accomplished via several means: branch breakage and recementation (Kawaguti, 1937; Shinn, 1972; Gilmore and Hall, 1976; Tunnicliffe, 1978; Highsmith et al., 1980), transverse division (Wells, 1956), or production of specialized buds or 'polyp-balls' (Scheer, 1959, 1960; Rosen and Taylor, 1969).

Here I describe an escape response utilized by the scleractinian coral Seriatopora hystrix Dana under unfavourable environmental conditions and term this 'polyp bail-out' (see Sammarco, 1981; in press). Since this phenomenon results in dispersal of the colony, it can be regarded as a distinctive and previously unrecognized new mode of asexual reproduction within the Scleractinia. Although the term 'polyp bail-out' is colloquial, it has been chosen because it both describes the process of active detachment and carries with it the connotation of the unfavourable circumstances under 


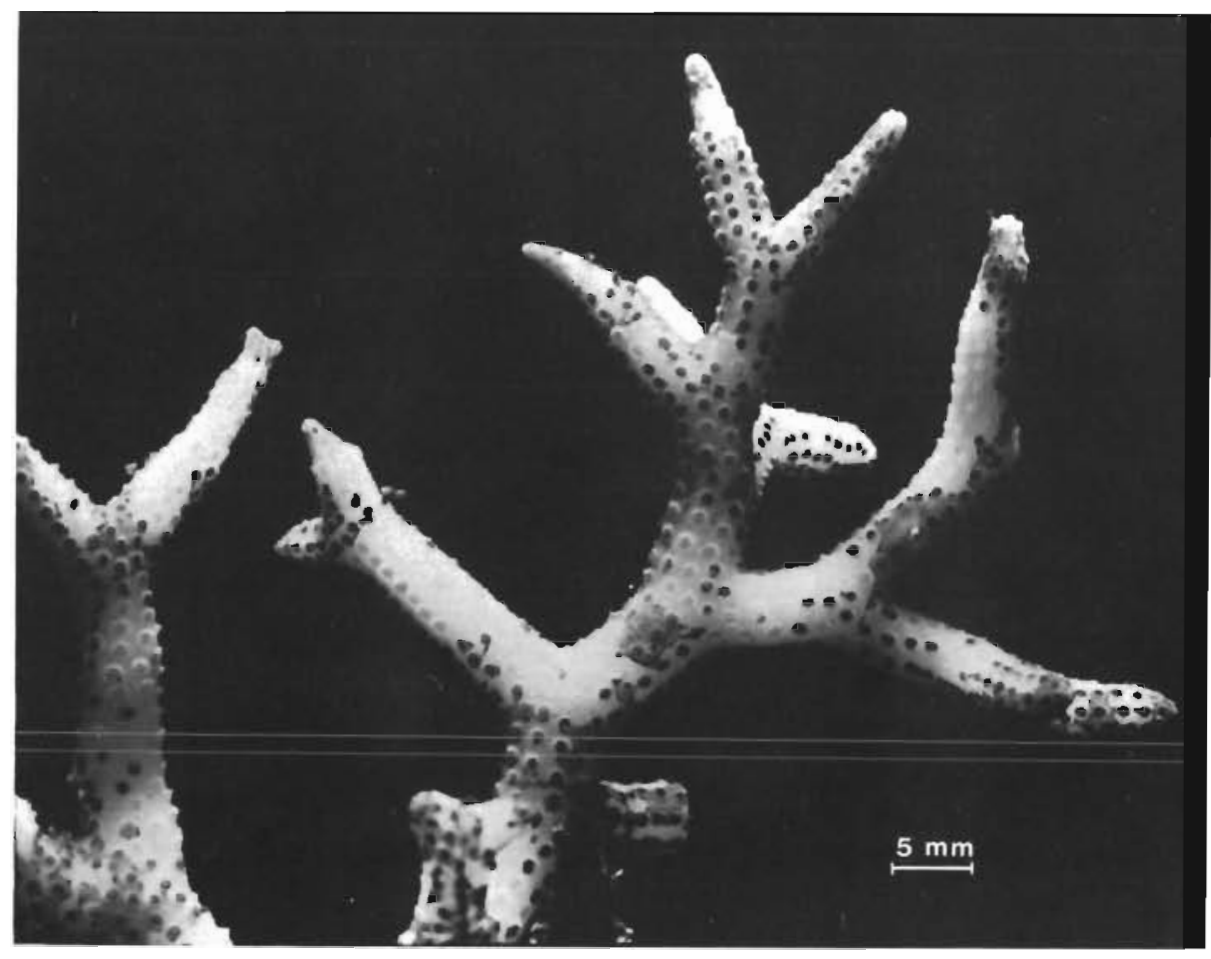

Fig. 1. Seriatopora hystrix. Mottled or spotted appearance exhibited under environmental stress, symptomatic of 'polyp bail-out' Photo by J. H. Carleton

which the phenomenon has been observed to occur. Three steps are involved: (1) coenosarc withdrawal and isolation of polyps; (2) detachment of polyps from the skeleton and release; (3) settlement and skeleton secretion by the newly freed polyps. Evidence is also presented here for strong seasonality in planulation within S. hystrix.

\section{MATERIALS AND METHODS}

All specimens were collected from, and field observations made on, Britomart and Davies Reefs, central region of the Great Barrier Reef $\left(18^{\circ} 15^{\prime} \mathrm{S}, 146^{\circ} 45^{\prime} \mathrm{E}\right.$ and $18^{\circ} 50^{\prime} \mathrm{S}, 147^{\circ} 40^{\prime} \mathrm{E}$, respectively). During a study of planulation spanning November 1979 to June 1981, colonies of the common shallow-water coral Seriatopora hystrix (see Veron and Pichon, 1976) were collected at approximately monthly intervals, returned to the laboratory, and examined for planulae. S. hystrix is a delicately branched coral commonly forming thickets $\leq 0.5 \mathrm{~m}$ in diameter. It usually has a uniform dark brown, tan, or pink color. In order to induce planulation, colonies were placed in non-aerated aquaria with non-circulating seawater. This technique is commonly used for collection of planulae from corals (Loya, pers. comm.). The mucus from the coral accumulates in the aquarium, and the stress which induces planulation in gravid coral colonies in this situation is probably a lowered concentration of oxygen caused by the coral itself and increasing bacterial populations (i.e. a high biological oxygen demand).

Aquaria were examined frequently over the next few days for release of planulae. When it was noted that individual polyps were detaching themselves from the skeleton, branches were collected and followed closely with a dissecting stereoscopic photo-microscope (Wild M-5A). Any extraordinary activities were documented accordingly.

Using a wide-mouth pipette, 250 polyps - which had detached naturally from several colonies during one sampling period - were carefully collected and transferred to labeled plastic jars containing clean seawater. Plastic Petri dishes and settling plates have been used successfully as a settling substrate for coral planulae both in the field (Wallace and Bull, in press; Neudecker, in press) and in the laboratory (unpubl. own data). This artificial substrate is apparently not as effective as natural dead coral in attracting coral settlement in the field (Wallace and Bull, in press) but operates effectively in the laboratory (unpubl. own data). It was decided not to use natural substrate under these laboratory conditions to facilitate observation of polyp development and to eliminate unnecessary additional sources of bacteria.

Individual polyps were monitored up to several times daily for $9 \mathrm{~d}$ to assess success of settlement and possible initiation of skeleton secretion. At the end of this period, sections of some jars containing polyps showing evidence of skeletenogenesis were excised 
with a watercooled rock-saw. In order to remove tissue from the skeleton, samples were bleached in standard sodium hypochlorite $(3.5 \%)$, rinsed in fresh water, and oven-dried at $55^{\circ} \mathrm{C}$. They were then mounted on labeled blocks for examination by scanning electron microscope.

\section{RESULTS}

\section{Laboratory Observations}

Several days after colonies were placed in the aquaria, they exhibited a blotchy or spotted appearance (Fig. 1). Closer examination revealed that this appearance was due to polyps detaching themselves from each other. Initially, the mottling of a colony was
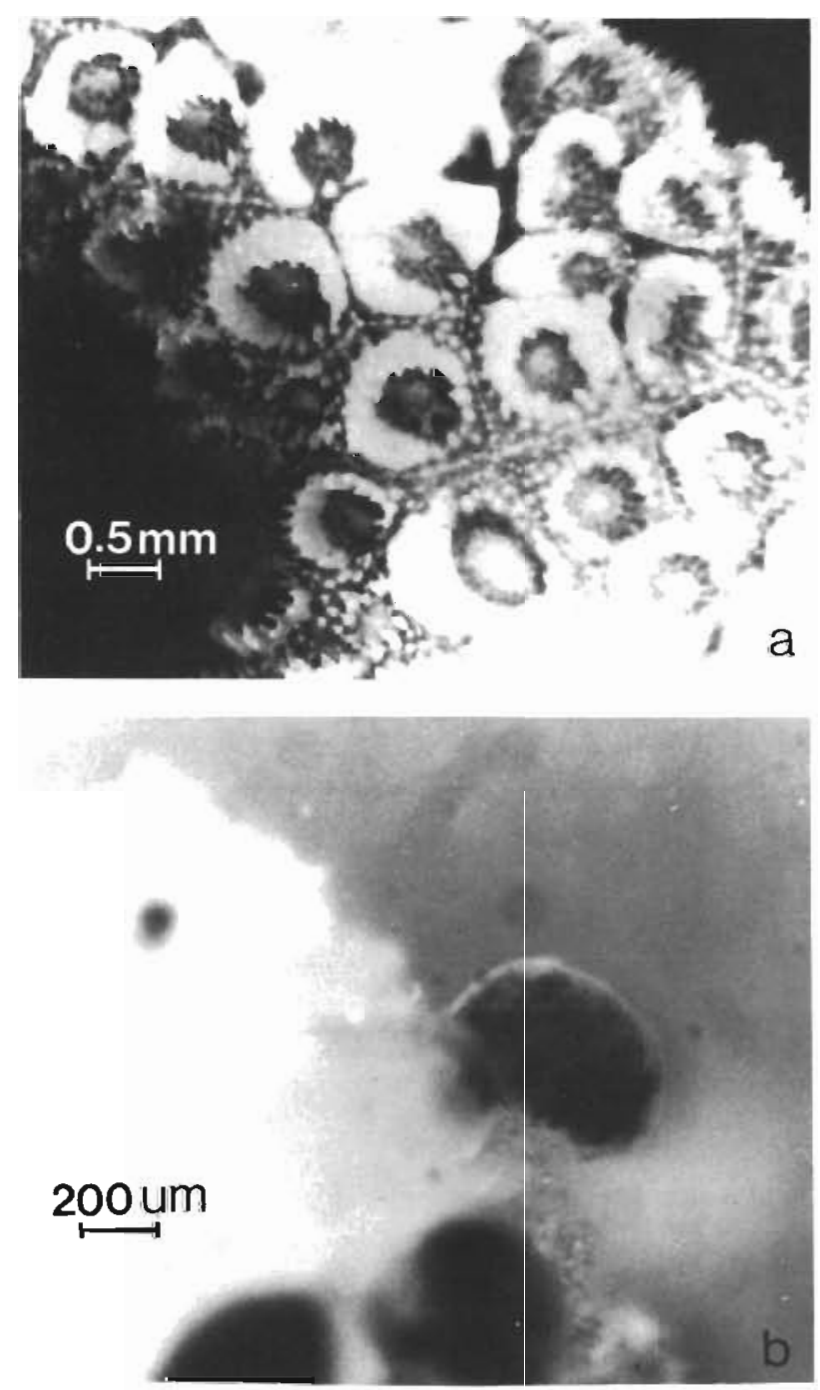

Fig. 2. Seriatopora hystrix. (a) Isolation of polyps is achieved during the initial stages of bail-out via withdrawal of coenosarc towards the polyps. (b) Polyp emerging from skeleton immediately prior to actual detachment achieved via polyp-ward movement of the coenosarc Brown spots on the surface of the coral were simply individual polyps surrounded by progressively thinning tissue and exposed skeleton (Fig. 2a). The tissue was seen being actively drawn with its zooxanthellae by the polyps from the area of the coenosarc. Within several hours, many polyps were joined only by thin strands of tissue which finally snapped apart and withdrew, leaving the polyps isolated. The actual mechanism by which tissue was withdrawn could not be discerned at this time. Frustules (minute planula-like, non-ciliated bodies; Hyman, 1940) were also produced.

The next step involved slow emergence of polyps from their calices and separation from the skeleton. Emergence of an individual polyp required a period of from 30 min to several hours (Fig. 2b). Total dissociation of all polyps in a given colony, however, required 2 to $3 \mathrm{~d}$. There was some sloughing of remaining coenosarc tissue at this time. Almost any water movement accelerated the dissociation of polyps and coenosarc. Transferring portions of colonies to clean seawater after polyp bail-out had begun did not appear to slow the phenomenon.

Newly emerged polyps usually exhibited a rounded oral surface with a distinguishable gastrovascular opening. Tentacles were not evident at this time, but zooxanthellae were retained throughout the process. The aboral portion of the detached polyp possessed two elongate but usually coiled filaments (possibly mesenterial filaments) which were capable of extension and retraction (Fig. 3).

In the laboratory experiment, polyps were observed to be slightly negatively buoyant, drifting slowly to the bottom of test containers. They appeared to have limited powers of mobility but were easily lifted from the bottom of the vessel and carried passively by any water movement. Once on the bottom, polyps mostly rotated, translated distances up to several $\mathrm{mm}$, and inverted. Active ciliary action generating a strong current was noted in the area of the gastrovascular opening, and this was maintained throughout the period of observation. It became apparent that the basal filaments were slightly adhesive, assisting in movement. They were initially retained in most polyps and then observed to be resorbed within $7 \mathrm{~d}$. Some polyps lost their filaments within $48 \mathrm{~h}$; (it is not known whether this was due to autotomy or was an artifact of handling).

For several days, there was very little change in the appearance of the polyps. Those that survived retained a generally vesicular shape, remaining free to be moved about within the test jars. Within 7 to $9 \mathrm{~d}$, however, some free polyps re-attached to the bottom, reoriented, and extended their tentacles. Of these, 


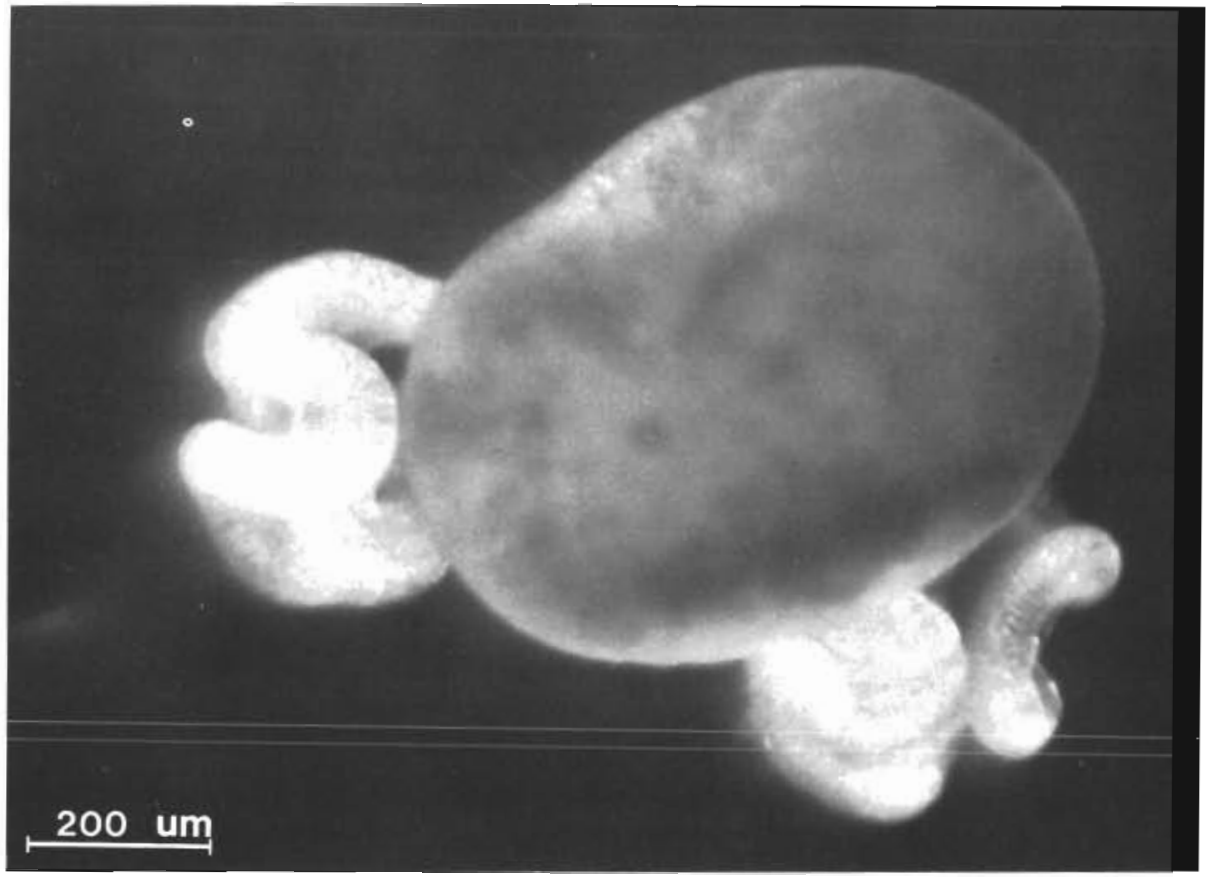

Fig. 3. Seriatopora hystrix. Freed polyp with 2, extensible, slightly adhesive basal filaments, shown directly subsequent to bail-out

some secreted a new skeleton (Fig. 4) from that portion of the calicoblastic ectoderm in contact with the substrate.

Of the 250 polyps monitored, $\leq 4.8 \%$ (2.6 to $8.2 \%$, $95 \%$ confidence limits) successfully settled, survived, and secreted skeletons within $9 \mathrm{~d}$. During this time, an additional $6 \%$ had successfully settled but had not yet secreted skeletons, $47.6 \%$ had settled but died, and
$41.6 \%$ died prior to settlement. Neither the frustules nor the pieces of free coenosarc survived. Some polyps and coenosarc tissue did remain on the skeleton. Neither, however, were observed to regenerate in this experiment.

A peak in planulation for Seriatopora hystrix occurred in November of both 1979 and 1980. Hundreds of planulae were obtained per colony at these times

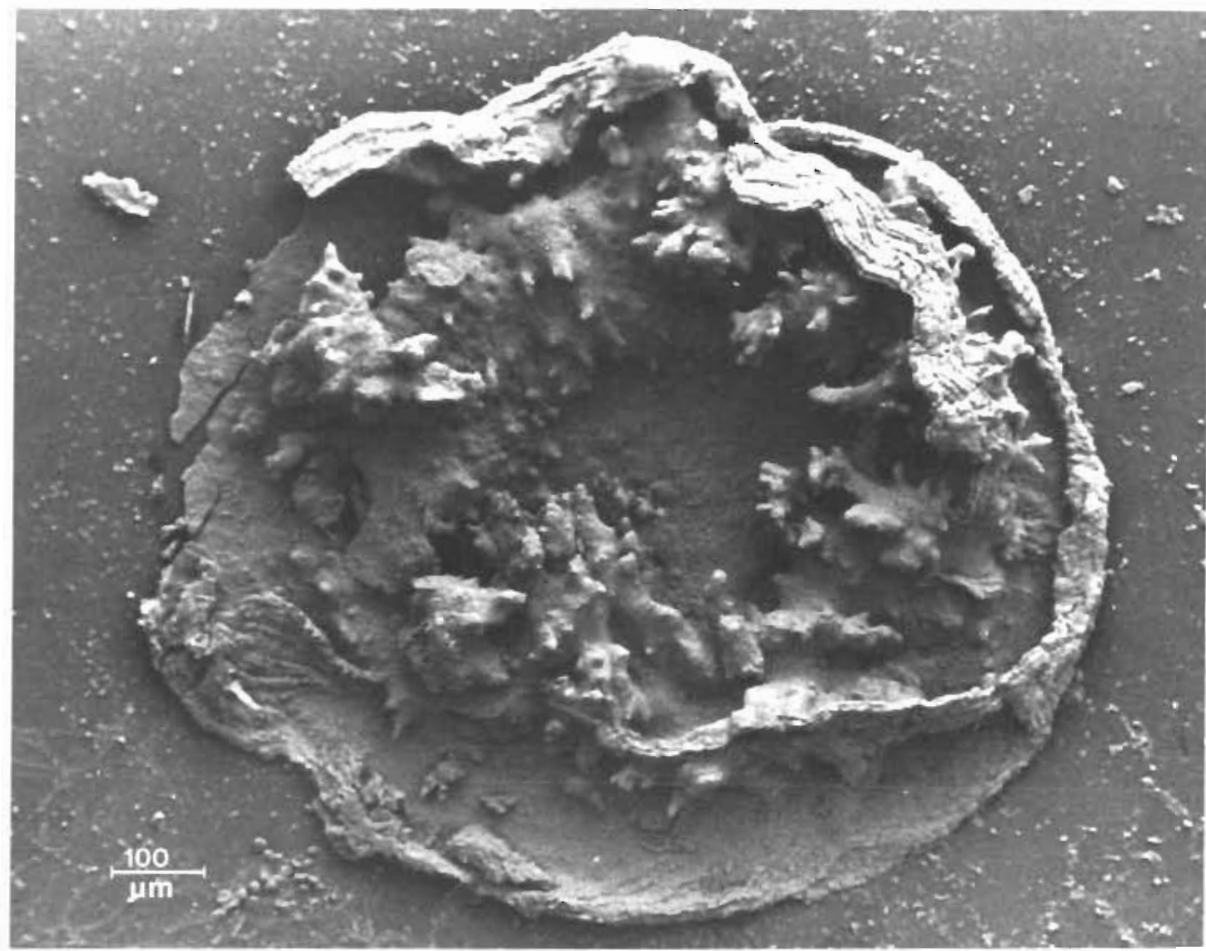

Fig. 4. Seriatopora hystrix. Scanning electron micrograph of initial calcium carbonate skeleton secreted by freed polyp 7 to $9 \mathrm{~d}$ after bail-out. Torqued aspect of septa due to lateral orientation of polyp during re-attachment 

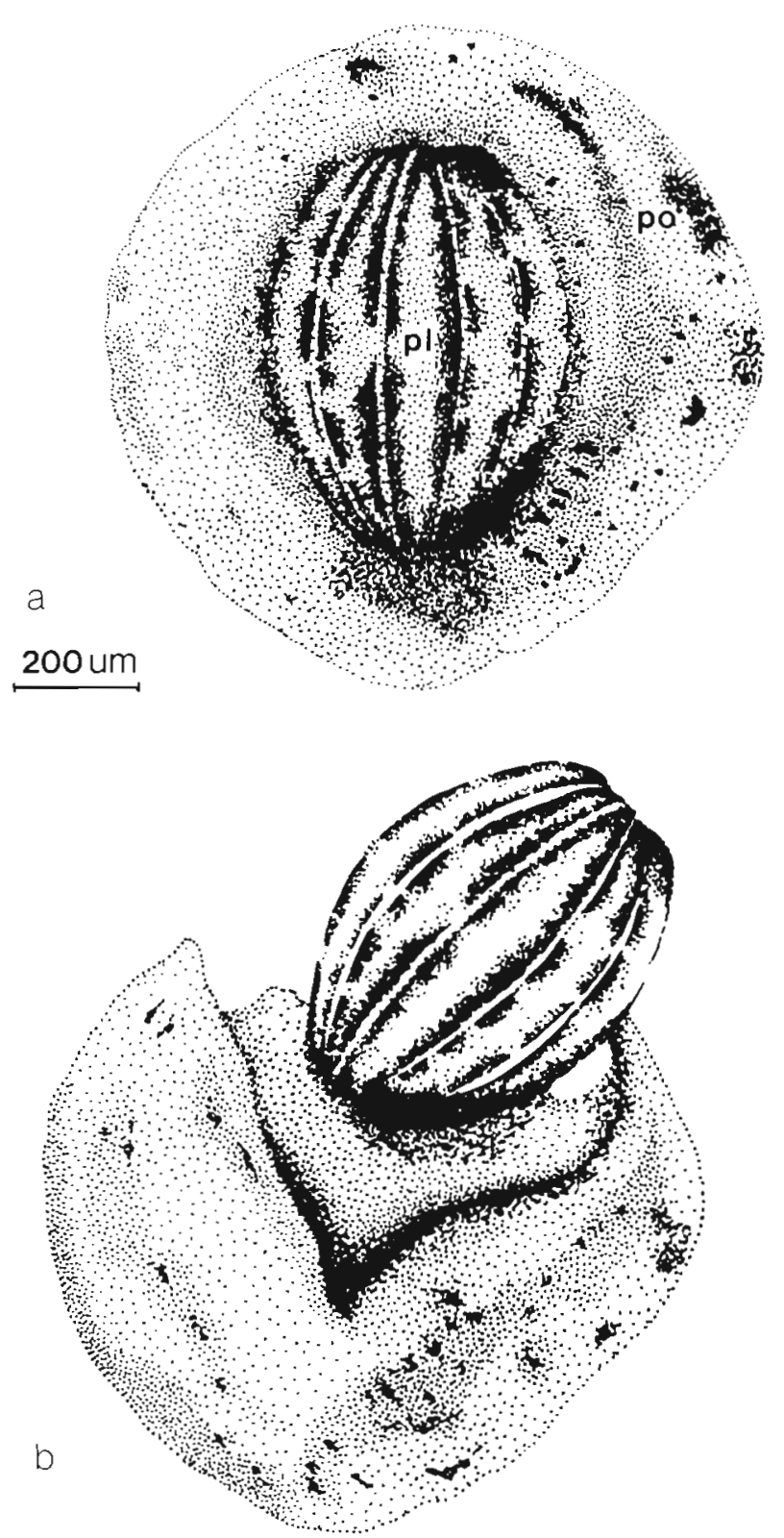

Fig. 5. Seriatopora hystrix. (a) Free polyp containing planula when bail-out was induced during November, the normal month for planulation. po polyp i pl planula. (b) Polyp disintegrated within $1 \mathrm{~h}$ after bail-out, freeing the planula which settled normally

while few ( 0 to 3 per colony) were abtained in all other months. Bail-out, on the other hand, could be induced during any collection period and at any time of the day.

When bail-out was induced during November, some of the isolated polyps contained a single active planula within the gastrovascular cavity (Fig. 5a). Within 1 or $2 \mathrm{~h}$ after dissociation from the skeleton, the free polyp disintegrated, releasing the planula (Fig. 5b). The larva settled normally and began secreting a skeleton.
Field Observations

The characteristic spotting of colonies in whole or part and actual dissociation of the polyps was observed in the field on both Britomart and Davies Reefs outside the normal spawning period. This occurred in an area where Seriatopora hystrix was clearly the dominant coral species. The event was documented photographically in situ (Fig. 6) with a Hasselblad 50 OEL/M camera in an underwater housing. No obvious adverse environmental conditions were apparent at the time of observation. The colonies also did not exhibit any obvious symptoms of predation or disease (although 'white-band disease' remains a possibility; see Antonius, in press $\mathrm{a}, \mathrm{b}$ ). It was not possible at the time to make estimates of distances of dispersal or percent survival in the field.

\section{DISCUSSION}

A spotted or blotchy appearance in corals along with sloughing of tissue from the skeleton has usually been interpreted as a sign of colony mortality. In Seriatopora hystrix, however, this appearance was determined to be a symptom of an escape response whereby polyps within a colony detach themselves both from each other and from the skeleton. It is known that many coelenterates can take on a vesicular form under unfavourable conditions, including lack of oxygen, and later regenerate (Campbell, 1974). This, however, has never been reported for a scleractinian coral. The free polyps may represent a form of reduction stage in development whereby polyps actually lose some of their morphological complexity, only to regenerate them later. For example, tentacles were not evident during and after bail-out and externally visible filaments were eventually resorbed or lost. Tentacles reappeared again several days later. Histological analyses are underway to investigate this problem (Crenshaw and Sammarco, work in progress)

Hyman (1940) has reported that the hydranths of some Hydroida (Coelenterata), upon exposure to adverse environmental conditions, detach from colonies. Such polyps, however, die shortly after detachment. In such cases, the coenosarc apparently remains on the original skeleton and regenerates new polyps once conditions permit. This regeneration was not observed under laboratory conditions in Seriatopora hystrix. In addition, once the process of bail-out was triggered, it appeared as though it could not be reversed (although this remains to be conclusively demonstrated).

During the normal spawning period, polyps which dissociate from the skeleton can carry within themselves live planulae, and these planulae can later be 
released to settle successfully. This adds an additional facet to the already interesting adaptation of polyp bail-out. A given colony stressed during the normal planulation period cannot only utilize a form of asexual reproduction as an escape response but may also retain its ability to reproduce sexually after experiencing an environmental stress - one which might otherwise have prevented successful spawning.

Little is known about the dispersal capabilities of reproductive propagules in scleractinian corals. Planulae such as those derived from Stylophora pistillata are ciliated and capable of swimming (Rinkevich and
Loya, 1979a, b). Fertilized eggs such as those derived from Goniastrea australensis Edwards and Haime are non-ciliated and slightly negatively buoyant but can be carried passively on the reef flat (Kojis and Quinn, 1981). These eggs also have an adhesive quality which assists them in becoming lodged in small crevices. The polyp-balls of Goniopora stokesi (Scheer, 1959, 1960; Rosen and Taylor, 1969) contain portions of a skeleton, are negatively buoyant, and as may be inferred from observations made by Rosen and Taylor (1969) and Sheppard (1981), appear to have limited dispersal capabilities
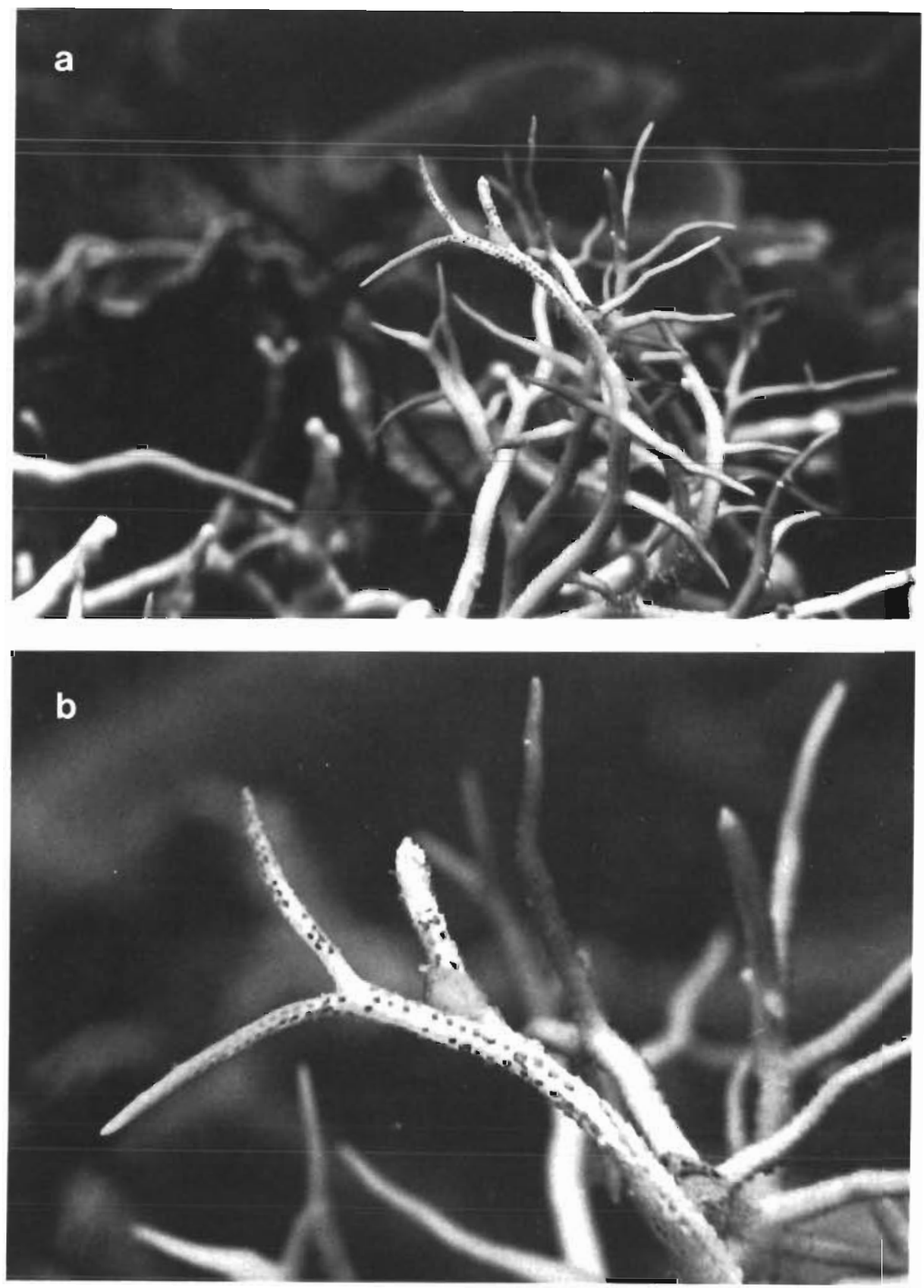

Fig. 6. Seriatopora hystrix. (a) Photograph of a colony exhibiting symptoms of polyp bail-out at a depth of 7 to $8 \mathrm{~m}$ on Davies Reef in the central region of the Great Barrier Reef. This particular area was dominated by $S$. hystrix. (b) Close-up of branch showing that most polyps have already dissociated while some are still in the process of dissociating. Photo by J. R. Strickler 
Free polyps derived from Seriatopora hystrix probably have dispersal capabilities at least equivalent to or better than those of the fertilized eggs of Goniastrea australensis, as they are small and light and carry no portion of a skeleton with them. Unfortunately, no data are available at present on the maximum distance of dispersal for any of these types of propagules, including planulae. Studies of the type conducted by $R$. Olson (pers. comm.; work in progress) on ascidian larvae at Lizard Island, Great Barrier Reef, where a diver actually follows larvae after release in the field, are presently underway (Crenshaw and Sammarco, work in progress). Preliminary results suggest that polyps are indeed capable of wide passive dispersal in natural currents of approximately 4 to $5 \mathrm{~cm} \mathrm{~s}^{-1}$. Current velocities on the reef flat of Britomart Reef are known to average $35 \mathrm{~cm} \mathrm{~s}^{-1}$, frequently reaching higher velocities (Wolanski and Jones, 1980).

This study is primarily a laboratory investigation which has opened many questions. At this point the types and intensities of natural stresses required to trigger bail-out are unknown. Desiccation or exposure to high light intensity upon emergence during extreme low tides or lowered salinity after heavy rains are likely candidates. Preliminary field experiments in which extreme low tides were simulated and colonies of Seriatopora hystrix were exposed to conditions like these did successfully induce bail out (Crenshaw and Sammarco, work in progress).

The phenomenon also introduces some interesting questions concerning its influence on the population. Bail-out essentially divides a colonial organism into thousands of independent, genetically identical individuals, each of which has the potential of developing into another colony. A clonal success rate of $\leqslant 5 \%$ could have a marked impact on the gene pool of a coral population. It is not known how well this estimate of survival of polyps in the laboratory relates to survival in the field. It is known, however, that maintaining experimental juvenile or adult corals alive in closed aquarium systems is commonly more difficult than maintaining them in the field.

The polyp-ball mode of reproduction in Goniopora stokesi is believed to have led to its dominance in certain soft-bottom habitats in the Chagos Archipelago (Sheppard, 1981). Bail-out has been observed in areas dominated by Seriatopora hystrix (Davies Reef, pers. comm.). Polyp bail-out could be one factor contributing to dominance of $S$. hystrix in certain shallow reef areas, just as branch breakage and recementation (e.g. Highsmith et al., 1980; Highsmith, 1982) and aggregative settlement of planulae (Lewis, 1974a; Bak and Engel, 1979; Sammarco, 1982; and others) can cause local dominance in other species of coral. Clearly, further research is needed in this area.
Environmental stress is known to trigger reproduction in many species of plants and animals. Harper (1977) cites numerous strategies which have evolved in terrestrial plants to escape physical stress and predation. In the aquatic environment, freshwater green filamentous algae of the genus Oedogonium produce and release zoospores in response to rises in temperature or decreases in light intensity (Klebs, 1928; Erben, 1962). In the invertebrates, some sponges produce gemmules asexually with the onset of winter (Hyman, 1940; Simpson and Fell, 1974). Some freshwater ectoprocts (e.g. Victorella pavida) form overwintering hibernacula as a response to natural fluctuations in temperature and salinity as well as to pollution and other unfavourable conditions (Carranda and Sacchi, 1964; Ryland, 1970; Bushnell and Rao, 1974). Some non-scleractinian coelenterates, particularly hydrozoans, produce resting stages under adverse conditions (Campbell, 1974).

Polyp bail-out is the process by which adult individuals within a sessile colony actively detach themselves from a hard skeleton, re-settle, and re-initiate new skeleton formation and colony growth elsewhere. This is a new mode of reproduction and escape response within the Scleractinia. The normal spawning period for Seriatopora hystrix in the central region of the Great Barrier Reef appears to be November, but bail-out can be induced at any time. The adaptive significance of polyp bail-out may lie in its value as a mode of dispersal for a scleractinian coral under conditions of environmental stress.

\section{CONCLUSIONS}

The major findings of this study are as follows:

(1) The scleractinian coral Seriatopora hystrix Dana utilizes a unique escape response to environmental stress, termed 'polyp bail-out'. This may also be considered a new form of asexual reproduction within the Scleractinia.

(2) Bail-out occurs in 3 steps: (a) withdrawal of coenosarc and isolation of individual polyps; (b) detachment of polyps containing zooxanthellae from the skeleton and release; (c) dispersal, settlement, and re-initation of skeletenogenesis by newly freed polyps.

(3) Under laboratory conditions, $\geq 5 \%$ of the free polyps successfully settled and began secreting new skeletons

(4) The normal period of peak planulation for Seriatopora hystrix in the central region of the Great Barrier Reef is November, but polyp bail-out may be induced at any time. Polyps which dissociate at this time are capable of carrying planulae with them which are later released to settle normally.

(5) Bail-out occurs naturally in the field. 
Acknowledgements. I thank A. I. Hatcher and J. H. Carleton for their assistance in both the field and the laboratory. Photographs are by J. H. Carleton, J. R. Strickler and the author, with much appreciated assistance from L. Brady. The manuscript has benefited greatly from comments made by $M$. J. Risk, J. S. Bunt, J. R. Strickler, G. R. Harbison, D. J. Barnes, J. E. N Veron, B. H. Brinkhuis, and H. Crenshaw. I also thank E. Lovell for helpful discussions and D. Brims for illustrations. This project was supported entirely by the Australian Institute of Marine Science, to which I am also indebted.

\section{LITERATURE CITED}

Atoda, K. (1947a). The larva and postlarval development of some reef-building corals. I. Pocillopora damicornis cespitosa (Dana). Sci. Rep. Tôhoku Univ. (4th Ser.) 18: 24-47

Atoda, K. (1947b). The larva and postlarval development of some reef-building corals. II. Stylophora pistillata (Esper). Sci. Rep. Tôhoku Univ, (4th Ser.) 18: 48-64

Atoda, K. (1951). The larva and postlarval development of some rocf-building corals. V. Seriatopora hystrix Dana. Sci. Rep. Tôhoku Univ. (Ser. 4) 19: 33-39

Antonius, A. (in press a). The band diseases in coral reefs. In: Gomez, E. (ed.) The reef and man. Proc. Fourth Int. Coral Reef Symp., Manila, 1981

Antonius, A. (in press b). Coral reef pathology: a review. In: Gomez, E. (ed.) The reef and man. Proc. Fourth Int. Coral Reef Symp., Manila, 1981

Bak, R. P. M., Engel, M. S. (1979), Distribution, abundance and survjval of juvenile corals (Scleractinia) and the importance of life history strategies in the parent coral community. Mar. Biol. 54: 341-352

Bushnell, J. H., Rao, K. S. (1974). Dormant or quiescent stages and structures among the Ectoprocta: physical and chemical factors affecting viability and germination of statoblasts. Trans. Am. microsc. Soc. 93 (4): 524-543

Campbell, R. D. (1974). Cnidaria. In: Giese, A. C., Pearse, J. S (eds.) Reproduction of marine invertebrates, Vol. 1. Academic Press, New York, pp. 133-200

Carranda, C. C., Sacchi, C. F. (1964). Ecology of Victorella. Vie Milieu 15: 389-426

Connell, J. H. (1974). Population ecology of reef building corals. In: Jones, O. A., Endean, R. (eds.) Biology and geology of coral reefs, Vol. 2. Academic Press, New York, pp. 205-245

Erben, K. (1962). Sporulation. In: Lewin, R. A. (ed.) Physiology and biochemistry of algae. Academic Press, New York, pp. 701-710

Gardiner, J. S. (1902). Some notes on variation and protandry in Flabellum rubrum and senescence in the same and other corals. Proc. Camb. phil. Soc. biol. Sci. 11 463-471

Giese, A. C., Pearse, J. S. (1974). Introduction: general principles. In: Giese, A. C., Pearse, J. S. (eds.) Reproduction of marine invertebrates. Academic Press, New York, Vol. 1. pp. $1-49$

Gilmore, M. D., Hall, B. R. (1976). Life history, growth habits, and constructional roles of Acropora cervicornis in the patch res:f environment. J. sedim. Petrol. 46 (3): 519-522

Harper, J. L. (1977). Population biology of plants. Academic Press, London

Harrigan, J. F. (1972). The planula larva of Pocillopora damicornis: Iunar periodicity of swarming and substratum selection behavior Ph. D. dissertation, University of Hawaii

Highsmith, R. C. (1982). Reproduction by fragmentation in corals. Mar. Ecol. Prog. Ser 7.207-226
Highsmith, R. C., Riggs, A. C., D'Antonio, C. M. (1980). Survival of hurricane-generated coral fragments and a disturbance model of reef calcification/growth rates. Oecologia 46: 322-329

Hyman, L. H. (1940). The invertebrates, Vol. I, Protozoa through Ctenophora. McGraw-Hill, New York

Kawaguti, S. (1937). On the physiology of reef corals. III. Regeneration and phototropism in reef corals. Palao Trop. Biol. Sta. Studies 1; 209-216

Klebs, G. (1928). Die Bedingungen der Fortpflanzung bei einigen Algen und Pilzen, Fischer, Jena

Kojis, B., Quinn, N. J. (1981). Aspects of sexual reproduction and larval development in the shallow-water hermatypic coral, Goniastrea australensis (Edwards and Haime, 1857). Bull. mar Sci. 31: 558-573

Kojis, B., Quinn, N. J. (in press). Reproduction in two species of Porites (Scleractinia). In: Gomez, E. (ed.) The reef and man, Proc. Fourth Int. Coral Reef Symp., Manila, 1981

Lewis, J. B. (1974a). Settlement and growth factors influencing the contagious distribution of some Atlantic reef corals. Proc. Second Int. Coral Reef Symp., Vol. 2, Great Barrier Reef Comm., Brisbane, pp. 201-206

Lewis, J. B. (1974b). The settlement behaviour of planulae larvae of the hermatypic coral Favia fragum (Esper). J. exp. mar. Biol. Ecol. 15: 165-172

Marshall, S. M., Stephenson, T. A. (1933). The breeding of reef animals, Part I, The corals. Scient. Rep. Gt Barrier Reef Exped. 3: 219-245

Rinkevich, B., Loya, Y. (1979a). The reproduction of the Red Sea coral Stylophora pistillata. I. Gonads and planulae. Mar Ecol. Prog. Ser. 1: 133-144

Rinkevich, B., Loya, Y. (1979b). The reproduction of the Red Sea coral Stylophora pistillata. II. Synchronization in breeding and seasonality of planulae shedding. Mar. Ecol. Prog. Ser. 1: 145-152

Rosen, B. R., Taylor, J. D. (1969). Reef coral from Aldabra: new mode of reproduction. Science, N. Y, 166: 119-121

Ryland, J. S. (1970). Bryozoans, Hutchinson Press, London

Sammarco, P. W. \{1981\}. A new mode of reproduction in corals under stress: is there life after death in Seriatopora? Aust. mar. Sci. Bull. 75: 20 (Abstract)

Sammarco, P. W (1982). Echinoid grazing as a structuring force in coral communities: whole reef manipulations. $J$. exp. mar. Biol. Ecol. 61: 31-55

Sammarco, P. W. (in press). Escape response and dispersal in an Indo-Pacific coral under stress: 'Polyp Bail-Out' In: Gomez, E. (ed.) The reef and man, Proc. Fourth Int. Coral Reef Symp., Manila, May 1981 (Abstract)

Scheer, G. (1959). Die Formenvielfalt der Riffkorallen. Bericht 1958/1959 Naturwissenschaftlichen Verein Darmstadt 50: $50-67$

Scheer, G. (1960). Viviparie bei Steinkorallen. Naturwissenschaften 47: 238

Sheppard, C. R. C. (1981). The reef and soft substrate coral fauna of Chagos, Indian Ocean. J. Nat. Hist. 15: 607-621

Shinn, E. A. (1972). Coral reef recovery in Florida and the Persian Gulf, Envtl. Conserv. Dept, Shell Oil Co., Houston

Simpson, T. L., Fell, P. E. (1974). Dormancy among the Porifera: gemmule formation and germination. Trans. Am. microsc. Soc. 93: 544-577

Stimson, J. S. (1976). Reproduction of some common Hawaiian reef corals. In: Mackie, G. O. (ed.) Coelenterate ecology and behavior Plenum Press, New York, pp. $271-279$

Stimson, J. S. (1978). Mode and timing of reproduction in some common hermatypic corals of Hawaii and Enewetak. Mar. Biol. 48: 173-184 
Tunnicliffe, V. (1978). The role of boring sponges in coral fracture. Colloq. Int. Cent. Nat. Recherche Scient., 291, Biologie des Spongiaires, pp. 309-315

Veron, J. E. N, Pichon, M. (1976). Scleractinia of Eastern Australia, Part I, Families Thamnasteriidae, Astrocoeniidae, Pocilloporidae. Australian Inst. Mar. Sci. Monogr. Ser., Vol. 1, Austral. Govt. Publ. Serv., Canberra
Wells, J. W. (1956). Evolution in the Fungiidae. In: Moore, R C. (ed.) Treatise on invertebrate paleontology; Coelenterata, University Kansas Press, Lawrence, pp. 223-245

Wolanski, W., Jones, M. (1980). Water circulation around Britomart Reef, Great Barrier Reef, during July 1979. Aust. J. mar. Freshwat. Res. 31:415-430

This paper was presented by Dr. J. Bunt; it was accepted for publication on July 30,1982 